\title{
Cloning and Expression of Clostridium acetobutylicum Endoglucanase, Cellobiase and Amino Acid Biosynthesis Genes in Escherichia coli
}

\author{
By H. ZAPPE, D. T. JONES AND D. R. WOODS* \\ Department of Microbiology, University of Cape Town, Rondebosch 7700, South Africa
}

(Received 28 October 1985; revised 3 January 1986)

Clostridium acetobutylicum P262 endoglucanase and cellobiase genes, cloned on a $4.9 \mathrm{~kb}$ DNA

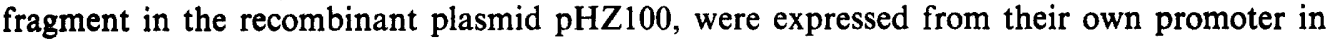
Escherichia coli. Active carboxymethylcellulase and cellobiase enzymes were produced, but there was no degradation of Avicel. The endoglucanase activities observed in cell extracts of $E$. coli $\mathrm{HB} 101(\mathrm{pHZ100})$ differed in their $\mathrm{pH}$ and temperature optima from those previously reported for $C$. acetobutylicum P270. Complementation of $E$. coli arg and his mutations by cloned $C$. acetobutylicum DNA was also observed.

\section{INTRODUCTION}

Acetone and butanol can be produced from a variety of carbohydrate substrates using Clostridium acetobutylicum. At present the economic feasibility of producing solvents by fermentation is limited by the high cost of starch- and sugar-based substrates (Lenz \& Moreira, 1980). The use of microbial strains which can utilize cellulosic substrates provides an alternative for the production of chemical feedstocks (Zeikus, 1980). Allcock \& Woods (1981) reported that C. acetobutylicum $\mathrm{P} 270$, an industrial strain which is a subculture of $C$. acetobutylicum $\mathbf{P 2 6 2}$, degraded amorphous cellulose substrates and showed low levels of carboxymethylcellulase (CMCase) and cellobiase activity, but no detectable activity against filter paper or Avicel. Since C. acetobutylicum was unable to degrade the crystalline cellulose substrate Avicel, it was concluded that the strain produced an inducible endoglucanase [endoglucanase is endo-1,4- $\beta$ glucanase or 1,4-(1,3;1,4)- $\beta$-D-glucan 4-glucanohydrolase (EC 3.2.1.4)] and a cellobiase [cellobiase is $\beta$-D-glucosidase or $\beta$-D-glucoside glucohydrolase (EC 3.2.1.21)]. Lee et al. (1985) reported that two additional $C$. acetobutylicum strains, NRRL B527 and ATCC 824, exhibited endoglucanase and cellobiase activities.

To characterize further and to improve the cellulase system of $C$. acetobutylicum, we constructed a gene bank of $C$. acetobutylicum DNA in Escherichia coli, and here we describe the cloning of a DNA fragment which contains an endoglucanase gene and a cellobiase gene.

\section{METHODS}

Bacteria, plasmids and growth conditions. C. acetobutylicum P262, which has weak CMCase activity, has been described previously (Allcock \& Woods, 1981; Allcock et al., 1982). E. coli HB101 (leuB6 trpE38 metE70 recAl3 supE44) (Boyer \& Roulland-Dussoix, 1969) and JC1553 (leuB6 hisGI recAl argG6 metB1 lacY1 gal-6 malAl $\left(\lambda^{\mathrm{R}}\right) x y l-7$ rpsL104 tonA2 tsx-1 $\lambda^{-}$supE44) (Clark \& Margulies, 1965) were used as recipient strains for recombinant plasmids. Plasmid pEcoR251, a gift from M. Zabeau, Plant Genetic Systems, Ghent, Belgium, is a positive selection vector containing the $E$. coli $E c o$ RI gene under the control of the $\lambda$ rightward promoter, the ampicillin (Ap) resistance gene and the pBR322 origin of replication. It was derived from the pCL plasmids described by Zabeau \& Stanley (1982). The EcoRI gene product expressed at high levels by the $\lambda$ promoter on pEcoR251 is lethal unless insertionally inactivated or regulated by plasmid pcI857, which contains a temperature

Abbreviations: CMCase, carboxymethylcellulase; CMC, carboxymethylcellulose; Ap, ampicillin; CBM, Clostridium basal medium. 
sensitive $\lambda$ repressor gene (Remaut et al., 1983). The $E c o R I$ gene has a single $B g h I$ cloning site. $C$. acetobutylicum P262 was grown in Clostridium Basal Medium (CBM) (O’Brien \& Morris, 1971) as described by Allcock et al. (1982). C. acetobutylicum was grown and protoplasts were prepared under stringent anaerobic conditions (Allcock et al., 1982). E. coli was grown in Luria medium and in minimal medium supplemented with specific carbon sources and amino acids (Maniatis et al., 1982). For $\beta$-galactosidase assays, cells were grown in broth containing $1 \mathrm{~mm}$-isopropyl thio- $\beta$-D-galactoside (IPTG). For alkaline phosphatase assays, cells were grown in the phosphatelimiting medium of Garen \& Levinthal (1960).

Preparation of DNA. Plasmid DNA was prepared by the alkali-hydrolysis method of Ish-Horowicz \& Burke (1981). C. acetobutylicum chromosomal DNA was prepared by the method of Marmur (1961), modified to overcome the high nuclease activity exhibited by $C$. acetobutylicum (Urano et al., 1983). C. acetobutylicum cultures (1 litre) at $\mathrm{OD}_{600} 0.5-0.6$ were harvested by centrifugation and resuspended in $40 \mathrm{ml} \mathrm{CBM}$ containing $10 \%(\mathrm{w} / \mathrm{v})$ sucrose, $12.5 \mathrm{mM}-\mathrm{MgCl}_{2}, 12.5 \mathrm{mM}-\mathrm{CaCl}_{2}$ and $5 \mathrm{mg}$ lysozyme ml-1 (Allcock et al., 1982). The development of protoplasts was monitored microscopically until approximately $90 \%$ protoplasts were obtained. SDS $(2 \%$, w/v, final concentration) was added under aerobic conditions and the lysed culture was extracted twice with phenol equilibrated with $10 \mathrm{~mm}$-Tris and $1 \mathrm{mM}$-EDTA, pH 7.5 (TE). The aqueous phase was then extracted twice with ether and dialysed against TE at $4{ }^{\circ} \mathrm{C}$. Ribonuclease treatment and further purification steps were as previously described by Marmur (1961).

Restriction enzymes. These were obtained from Boehringer Mannheim, and used according to the manufacturer's specifications.

Construction of a $C$. acetobutylicum P262 genomic library and cloning of cellulase genes. C. acetobutylicum chromosomal DNA was partially digested with Sau3A and fractionated on a sucrose density gradient (Maniatis $e$ t al., 1982). Chromosomal Sau3A fragments (4-7 kb) were ligated (T4 DNA ligase, Boehringer) with pEcoR251 which had been previously digested with $B g l$ II. The ligated DNA was used to transform competent (Dagert \& Ehrlich, 1979) E. coli $\mathrm{HB} 101$ cells, and transformants containing recombinant pEcoR251 plasmids were selected on Luria agar containing Ap $\left(50 \mu \mathrm{g} \mathrm{ml}^{-1}\right)$. E. coli $\mathrm{HB} 101 \mathrm{Ap}^{\mathrm{r}}$ colonies were pooled and recombinant $\mathrm{pEcoR} 251$ plasmid DNA was isolated and used to retransform E. coli HB101 and JC1553. E. coli JC1553 transformants were selected on minimal medium with Ap and appropriate nutritional supplements. Transformed $E$. coli HB101 cells were selected on Luria agar containing low viscosity carboxymethylcellulose (CMC) (5 $\mathrm{g} \mathrm{l}^{-1}$ ) (Sigma no. C-8758; degree of substitution 0.7 ) and Ap. Colonies were replica plated, and the original plates were washed free of any remaining bacteria before staining with Congo red $(0 \cdot 1 \%$, w/v), followed by destaining with $1 \mathrm{M}-\mathrm{NaCl}$ ( $\mathrm{Teather} \&$ Wood, 1982). Colonies showing CMCase activity were identified by a clear zone beneath the colony. The pHZ100 recombinant plasmid containing the $C$. acetobutylicum $\mathrm{P} 262$ cellulase genes was characterized by restriction mapping using standard procedures (Maniatis et al., 1982).

Southern blot hybridization. Chromosomal DNA from C. acetobutylicum was digested to completion with PstI, $H i n d I I I, E c o$ RI and $B g / I I$. The digested DNA fragments were fractionated by electrophoresis in $0 \cdot 7 \%(\mathrm{w} / \mathrm{v})$ agarose gels in Tris/acetate buffer and transferred to Gene Screen nitrocellulose filters (New England Corp.) (Southern, 1975). pHZ100, nick-translated with $\left[\alpha^{-32}\right.$ P]ATP, was used as a hybridization probe (Rigby $e t$ al., 1977).

Preparation of cell-free extracts and periplasmic proteins. Cell-free extracts were prepared from $200 \mathrm{ml}$ overnight $E$, coli cultures containing $\mathrm{pHZ100}$. The cells were harvested, washed and resuspended in $15 \mathrm{ml} \mathrm{PC}$ buffer (50 mM$\mathrm{K}_{2} \mathrm{HPO}_{4}, 12.5 \mathrm{~mm}$-citric acid, pH 6.3) (Cornet et al., 1983b). The cells were freeze-thawed using liquid nitrogen and disrupted further by sonication on ice (10 s bursts for a total of $100 \mathrm{~s})$. The preparation was clarified by centrifugation for $15 \mathrm{~min}$ at $27000 \mathrm{~g}$ and samples were stored at $-70^{\circ} \mathrm{C}$. Periplasmic protein fractions were prepared by the chloroform treatment method of Ames et al. (1984).

Cellulase enzyme assays. Enzyme activity against CMC, acid-swollen cellulose and filter paper was determined by the release of glucose equivalents, as detected by the dinitrosalicylic acid method for reducing sugars (Miller, 1959). Activity against medium-viscosity CMC (Sigma no. C4888; degree of substitution $0 \cdot 7$ ) was assayed by incubating $50 \mu \mathrm{l}$ cell-free extract with $1 \mathrm{ml} 1.5 \%(\mathrm{w} / \mathrm{v}) \mathrm{CMC}$ in PC buffer at $50^{\circ} \mathrm{C}$ for $10 \mathrm{~min}$. Acid-swollen cellulose (Whatman CF11) was prepared by the method of Tansey (1971) and was resuspended in PC buffer. Enzyme activity was assayed by incubating $0.8 \mathrm{ml}$ cellulose suspension $(20 \mathrm{mg}$ dry weight ml-1) with $0.2 \mathrm{ml}$ enzyme solution for $30 \mathrm{~min}$ at $50^{\circ} \mathrm{C}$. Activity against filter paper (Whatman no. 1) was determined by incubating a $50 \mathrm{mg}$ strip of filter paper in $0.8 \mathrm{ml} \mathrm{PC}$ buffer with $0.2 \mathrm{ml}$ enzyme solution for $0.5-24 \mathrm{~h}$ at 40 and $50^{\circ} \mathrm{C}$. Activity against Avicel was determined by incubating $0.2 \mathrm{ml}$ enzyme solution with $1 \mathrm{ml} \mathrm{0.5 \%}$ Avicel PH-102 (FMC Corp.) in PC buffer for $24 \mathrm{~h}$ at 40 and $50^{\circ} \mathrm{C}$.

Protein concentrations in cell-free extracts were determined by the Lowry method. Activities of $\beta$-galactosidase and alkaline phosphatase in periplasmic fractions were assayed by the methods of Pardee et al. (1959) and Garen \& Levinthal (1960) respectively.

Cellobiase activity. The presence of cellobiase was determined by the production of acid and gas in peptone water containing cellobiose $\left(10 \mathrm{~g}^{-1}\right)$, and by growth on minimal medium containing cellobiose $\left(2 \mathrm{~g}^{-1}\right)$ as the sole carbon source. 


\section{RESULTS}

Complementation of E. coli amino acid auxotrophs. E. coli $\mathrm{JC} 553 \mathrm{Arg}^{+}$and $\mathrm{His}^{+}$transformants were isolated on supplemented minimal medium lacking either arginine or histidine, and containing Ap. Plasmid DNA was isolated from each transformant and used to retransform the $E$. coli auxotroph. In the retransformation experiments complementation of either the $\mathrm{Arg}^{-}$or $^{-}$ $\mathrm{His}^{-}$phenotype was always associated with transformation of the recipient strain to $\mathrm{Ap}^{\mathrm{r}}$. The $C$. acetobutylicum P262 origin of the insert was confirmed by Southern hybridization (data not shown).

Cloning of C. acetobutylicum P262 cellulase genes. E. coli HB101 was transformed with recombinant $\mathrm{pEcoR} 251$ plasmid pools and six transformants were isolated which produced a clear zone beneath the colony on CMC Luria agar. Each contained a pEcoR251 recombinant plasmid, and one of these plasmids, designated pHZ100, was selected for further study. The plasmid origin of the CMCase activity was confirmed by retransformation of $E$. coli HB101. CMCase activity was always associated with transformation to $\mathrm{Ap}^{\mathrm{r}}$.

Origin of DNA inserts. The origin of the cloned fragment on $\mathrm{pHZ100}$ was determined by Southern blotting with ${ }^{32}$ P-labelled pHZ100 as the probe (Fig. 1). Chromosomal DNA from $C$. acetobutylicum was digested to completion with PstI, HindIII, EcoRI or BglII. pHZ100 was nicktranslated and hybridized to a nitrocellulose filter prepared from the agarose gel depicted in Fig. $1(a)$. A Pst I digest of $\lambda$ was used for size markers (Fig. $1 a$, lane 1). The $14 \mathrm{~kb}$ fragment was a combination of the $11.5 \mathrm{~kb}$ fragment, which contains the $\lambda$ rightward promoter, and the $2.56 \mathrm{~kb}$ fragment linked by the $\lambda \cos$ site. Therefore both the 14 and $11.5 \mathrm{~kb}$ fragments hybridized with the $\mathrm{pEcoR} 251$ region of $\mathrm{pHZ} 100$ due to the presence of the $\lambda$ rightward promoter on $\mathrm{pEcoR} 251$ (Fig. 1b, lane 1). The number of hybridization bands in lanes 2-5 (Fig. 1b) confirmed the restriction map of the insert shown in Fig. 2. The smallest hybridization fragment present in the EcoRI digest (Fig. $1 b$, lane 3) corresponded to the internal fragment generated by EcoRI digestion of $\mathrm{pHZ100}$. The PstI site mapped at the extreme end of the insert, resulting in a very weak second hybridization fragment (Fig. 1b, lane 5). pEcoR251 did not show any homology with $C$, acetobutylicum DNA (data not shown).

Cellulase and cellobiase activities. E. coli $\mathrm{HB101}(\mathrm{pHZ100)}$ produced acid and gas in peptone water containing cellobiose, and grew on minimal medium with cellobiose as the sole carbon source. E. coli $\mathrm{HB} 101$ and $E$. coli $\mathrm{HB} 101$ (pBR322) were unable to utilize cellobiose. $E$. coli HB101(pHZ100) gave no reaction in peptone water lacking cellobiose.

Cell extracts were prepared from $E$. coli HB101(pHZ100) and assayed for activity against $\mathrm{CMC}$, acid-swollen cellulose and filter paper. Enzyme activities of 287,17 and $12 \mu \mathrm{g}$ glucose equivalents released (mg protein) ${ }^{-1} \mathrm{~min}^{-1}$ were obtained respectively (means of six experiments; standard errors of means were less than $20 \%$ of the reported values). Although activity against filter paper was detected initially, no further degradation and release of glucose equivalents occurred after $2 \mathrm{~h}$ at either 40 or $50^{\circ} \mathrm{C}$. No hydrolysis of Avicel was detected over $24 \mathrm{~h}$ at 40 or $50^{\circ} \mathrm{C}$.

Localization and characterization of CMCase activity in E. coli HB101( $p H Z 100)$. Localization of the CMCase activity in cell extracts indicated that periplasmic samples contained $75 \%$ of the total CMCase activity. Control experiments showed that $1.3 \%$ of the total $\beta$-galactosidase activity but $33 \%$ of the total alkaline phosphatase activity were present in the periplasmic preparations (means of three experiments; standard errors of means were less than $5 \%$ of the reported values). Supernatant samples showed no detectable CMCase or filter paper activity.

The optimum $\mathrm{pH}$ for CMCase activity of cell extracts was measured in different citrate (pH 3.0-6.5) and phosphate (pH 7.0-8.0) buffers. CMCase activity was totally inhibited at $\mathrm{pH} 3.75$. The optimum $\mathrm{pH}$ for enzyme activity showed a plateau between $\mathrm{pH} 5.0$ and 7.0; the activity decreased rapidly above $\mathrm{pH} 7.0$, and $<50 \%$ of the optimum activity remained at $\mathrm{pH} 8.0$. The optimum temperature for CMCase activity was $50^{\circ} \mathrm{C}$ at $\mathrm{pH} 6.3$. The CMCase activity in cell extracts was completely stable for 4 months at $-70^{\circ} \mathrm{C}$. 


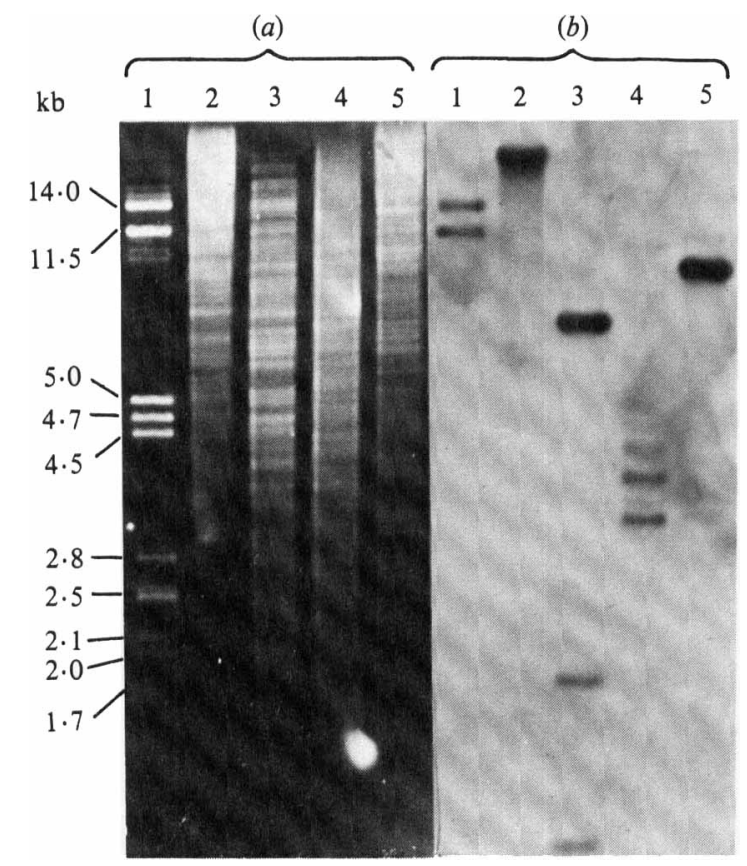

Fig. 1. (a) Agarose gel $(0.7 \%, \mathrm{w} / \mathrm{v})$ electrophoresis of total digests of $C$. acetobutylicum DNA cleaved with BglII (lane 2), EcoRI (lane 3), HindIII (lane 4) and PstI (lane 5). Lane 1, PstI-digested $\lambda$ DNA as size standards. (b) Autoradiograph of ${ }^{32} \mathrm{P}$-labelled $\mathrm{pHZ} 100$ hybridized to a DNA blot prepared from (a).

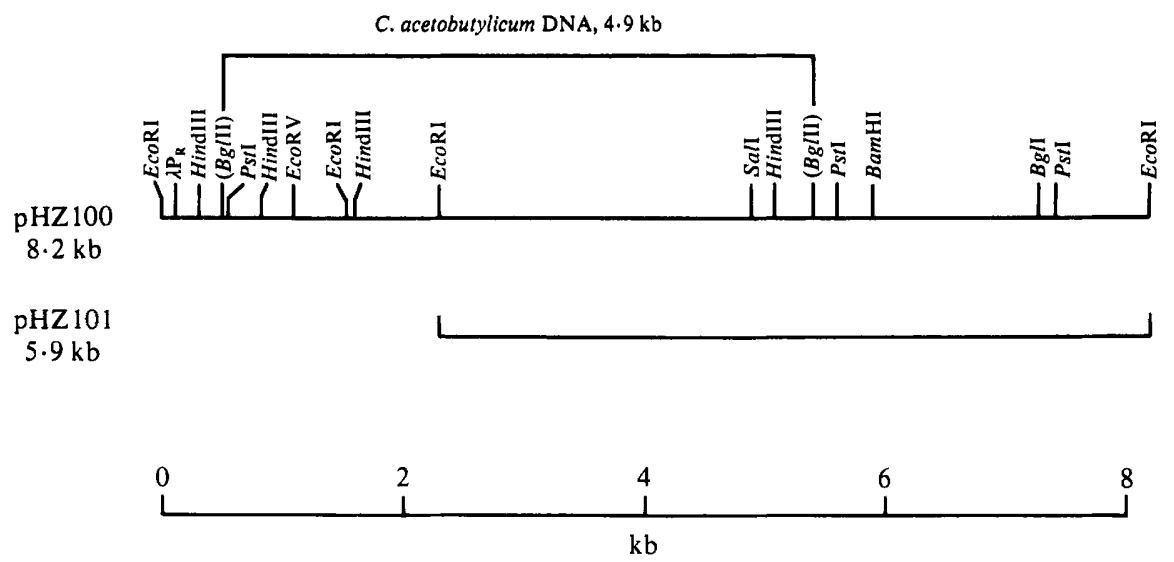

Fig. 2. Restriction and deletion map of pHZ100. The $B g / \mathrm{II}$ sites were lost during cloning. pHZ100 and $\mathrm{pHZ101}$ both expressed endoglucanase activity.

Restriction endonuclease mapping of the cloned C. acetobutylicum DNA fragment. The restriction endonuclease map of pHZ100 was obtained by digestion with the following $6 \mathrm{bp}$ recognition restriction enzymes: $A v a \mathrm{I}, B a m \mathrm{HI}, B c I \mathrm{I}, B g I \mathrm{I}, B g l \mathrm{II}, C l a \mathrm{I}, E c o \mathrm{RI}, E c o \mathrm{RV}, H i n d \mathrm{III}, H p a \mathrm{I}, K p n \mathrm{I}$, PstI, PvuI, PvuII, SacI, SalI, SmaI, SphI, XbaI and XhoI. The $4.9 \mathrm{~kb}$ C. acetobutylicum DNA fragment was cleaved by only five of the restriction enzymes tested; it contained single restriction sites for SalI, PstI and EcoRV, two sites for EcoRI and three sites for HindIII (Fig. 2). 
A deletion plasmid, pHZ101, was constructed by digestion of $\mathrm{pHZ100}$ with EcoRI. This resulted in the removal of the $\lambda$ rightward promoter and $1.8 \mathrm{~kb}$ of the $C$. acetobutylicum insert. The expression of the endoglucanase gene in pHZ101 was not affected and was identical to that observed in $\mathrm{pHZ} 100$.

\section{DISCUSSION}

Allcock \& Woods (1981) reported that $C$. acetobutylicum P270, a subculture of P262, had inducible, extracellular CMCase and cellobiase activity but did not degrade filter paper. In comparison with other cellulolytic bacteria and fungi, the levels of endoglucanase and cellobiase obtained in C. acetobutylicum P270 were low, and hydrolysis of insoluble cellulose substrates was not demonstrated in extracellular or intracellular fractions. We have cloned and characterized cellulase genes from $C$. acetobutylicum P262. The $E$. coli extracts were able to hydrolyse filter paper, but only at low levels for the first $2 \mathrm{~h}$ of the assay, suggesting that the cloned cellulase genes were only able to hydrolyse the amorphous cellulose in the filter paper and not the crystalline cellulose. The presence of endoglucanase activity and absence of exoglucanase activity were confirmed by the lack of hydrolysis of Avicel over $24 \mathrm{~h}$.

The conditions for optimum activity of the endoglucanase from C. acetobutylicum $\mathrm{P} 270$ and $E$. coli $\mathrm{HB} 101$ ( $\mathrm{pHZ100}$ ) differed. The optimum $\mathrm{pH}$ and temperature for the C. acetobutylicum $\mathrm{P} 270$ extracellular CMCase activity was pH 4.6 and $37^{\circ} \mathrm{C}$, whereas for the CMCase of $E$. coli HB101(pHZ100) periplasmic extracts it was $\mathrm{pH} 5 \cdot 0-7.0$ and $50^{\circ} \mathrm{C}$. This difference could be due to the possibility that $C$. acetobutylicum contains more than one endoglucanase gene. Cloning of endoglucanase genes from Clostridium thermocellum has revealed seven distinct DNA fragments coding for endoglucanases and three further fragments coding for cellobiasehydrolases (Millet $e t$ al., 1985). In C. acetobutylicum P270 the CMCase activity was inducible and a small molecule present in molasses was required for induction. The $C$. acetobutylicum P262 CMCase activity in cell-free extracts from $E$. coli containing $\mathrm{pHZ100}$ did not require molasses for induction and was expressed constitutively. The cellulase genes from $C$. acetobutylicum in $E$. coli were expressed from their own promoter and were not regulated by the $\lambda$ rightward promoter situated on pEcoR251.

Localization experiments indicated that the CMCase activity occurred predominantly in periplasmic fractions in $E$. coli cells containing the cloned gene. Cornet et al. (1983a) reported that the cloned $C$. thermocellum CMCase activity in $E$. coli was about equally distributed between the periplasmic and cytoplasmic compartments. The appearance of zones of hydrolysis on CMC plates was presumably due to the release of the endoglucanase by cell lysis.

Although the expression of other Clostridium genes in $E$. coli has been reported (Cornet $e t$ al., $1983 \mathrm{~b}$; Ishii et al., 1983), this is the first report that amino acid synthesis genes and cellulase genes from $C$. acetobutylicum can be expressed from their own promoters in $E$. coli. Since the transfer of plasmids by transformation (Lin \& Blaschek, 1984) and conjugation (Oultram \& Young, 1985) to $C$. acetobutylicum has been demonstrated, the opportunity exists to transfer the cloned cellulase genes back into $C$. acetobutylicum. This will enable a study of the expression of the cloned cellulase genes in this solvent-producing bacterium.

We thank M. L. Hunt for excellent technical assistance. This work was supported by grants to D. R. W. from Sentrachem Limited, Johannesburg, South Africa and the South African Council for Scientific and Industrial Research.

\section{REFERENCES}

Allcock, E. R. \& Woods, D. R. (1981). Carboxymethyl cellulase and cellobiase production by Clostridum acetobutylicum in an industrial fermentation medium. Applied and Environmental Microbiology 41, 539-541.

AllCOCK, E. R., ReID, S. J., Jones, D. T. \& Woods, D. R. (1982). Clostridium acetobutylicum protoplast formation and regeneration. Applied and Environmental Microbiology 43, 719-721.

Ames, G. F., Prody, C. \& Kustu, S. (1984). Simple, rapid, and quantitative release of periplasmic proteins by chloroform. Journal of Bacteriology 160, 1181-1183.

Boyer, H. W. \& Roulland-Dussoix, D. (1969). A 
complementation analysis of the restriction and modification of DNA in Escherichia coli. Journal of Molecular Biology 41, 459-472.

Clark, A. J. \& Margulies, A. D. (1965). Isolation and characterization of recombination-deficient mutants of Escherichia coli K12. Proceedings of the National Academy of Sciences of the United States of America 53, 451-459.

Cornet, P., Millet, J., Beguin, P. \& Aubert, J. (1983a). Characterization of two cel (cellulose degradation) genes of Clostridium thermocellum coding for endoglucanases. Biotechnology 1, 589-594.

Cornet, P., Tronik, D., Millet, J. \& Aubert, J. $(1983 \mathrm{~b})$. Cloning and expression in Escherichia coli of Clostridium thermocellum genes coding for amino acid synthesis and cellulose hydrolysis. FEMS Microbiology Letters 16, 137-141.

Dagert, M. \& Ehrlich, S. D. (1979). Prolonged incubation in calcium chloride improves the competence of Escherichia coli cells. Gene 6, 23-28.

Garen, A. \& LeVinthal, C. (1960). A fine-structure genetic and chemical study of the enzyme alkaline phosphatase of E. coli. I. Purification and characterization of alkaline phosphatase. Biochimica et biophysica acta 38, 470-483.

ISH-HoRowicz, D. \& BURKE, J. F. (1981). Rapid and efficient cosmid cloning. Nucleic Acids Research 9, 2989-2998.

IsHI, K., Kudo, T., HoNdA, H. \& HoRIKoshI, K. (1983). Molecular cloning of $\beta$-isopropylmalate dehydrogenase gene from Clostridium butyricum M588. Agricultural Biological Chemistry 47, 2313-2317.

LEE, S. F., ForsberG, C. W. \& GibBins, L. N. (1985). Cellulolytic activity of Clostridium acetobutylicum. Applied and Environmental Microbiology 50, 220-228.

LenZ, T. G. \& Moreira, A. R. (1980). Economic evaluation of the acetone-butanol fermentation. Industrial and Engineering Chemistry. Product and Research Development 19, 478-483.

LIN, Y.-L. \& BLASCHEK, H. P. (1984). Transformation of heat-treated Clostridium acetobutylicum protoplasts with pUB110 plasmid DNA. Applied and Environmental Microbiology 48, 737-742.

Maniatis, T., Fritsch, E. F. \& SAmbrooK, J. (1982). Molecular Cloning: a Laboratory Manual. Cold Spring Harbor, NY: Cold Spring Harbor Laboratory.

MARMUR, J. (1961). A procedure for the isolation of deoxyribonucleic acid from micro-organisms. Journal of Molecular Biology 3, 208-218.

Miller, G. L. (1959). Use of dinitrosalicylic acid reagent for determination of reducing sugar. Analytical Chemistry 31, 426-428.

Millet, J., Pétré, D., Beguin, P., Raynaud, O. \& AUBERT, J. (1985). Cloning of ten distinct DNA fragments of Clostridium thermocellum coding for cellulases. FEMS Microbiology Letters 29, 145-149.

O'BRIEN, R. W. \& MORRIS, J. G. (1971). Oxygen and the growth and metabolism of Clostridium acetobutylicum. Journal of General Microbiology 68, 307-318.

Oultram, J. D. \& Young, M. (1985). Conjugal transfer of plasmid pAM1 from Streptococcus lactis and Bacillus subtilis to Clostridium acetobutylicum. FEMS Microbiology Letters 27, 129-134.

PARdee, A. B., JACOB, F. \& Monod, J. (1959). The genetic control of cytoplasmic expression of "inducibility" in the synthesis of $\beta$-galactosidase by $E$. coli. Journal of Molecular Biology 1, 165-178.

Remaut, E., TsaO, H. \& FiERs, W. (1983). Improved plasmid vectors with a thermoinducible expression and temperature regulated runaway replication. Gene 22, 103-113.

Rigby, P. W. J., Dieckmann, M., Rhodes, C. \& BerG, P. (1977). Labelling deoxyribonucleic acid to high specific activity in vitro by nick translation with DNA polymerase 1. Journal of Molecular Biology 113, 237-251.

SOUTHERN, E. M. (1975). Detection of specific sequences among DNA fragments separated by gel electrophoresis. Journal of Molecular Biology 98, 503-517.

TANSEY, M. R. (1971). Agar-diffusion assay of cellulolytic ability of thermophilic fungi. Archives of Microbiology 77, 1-11.

Teather, R. M. \& Wood, P. J. (1982). Use of Congo red-polysaccharide interactions in enumeration and characterization of cellulolytic bacteria from the bovine rumen. Applied and Environmental Microbiology 43, 777-780.

Urano, N., Karube, I., Suzuki, S., Yamada, Y., HirochiKa, H. \& SAKAGUCHI, K. (1983). Isolation and partial characterization of large plasmids in hydrogen-evolving bacterium Clostridium butyricum. European Journal of Applied Microbiology and Biotechnology 17, 349-354.

ZabeaU, M. \& Stanley, K. K. (1982). Enhanced expression of cro- $\beta$-galactosidase fusion proteins under the control of the Pr promoter of bacteriophage lambda. EMBO Journal 1, 1217-1224.

ZEIKUS, J. G. (1980). Chemical and fuel production by anaerobic bacteria. Annual Review of Microbiology 34, 423-464. 